Supporting Information for

\title{
Molecular Light Switches for Calf Thymus DNA Based on Three Ru(II) Bipyridyl Complexes with Variations of Heteroatoms
}

\author{
Mei-Jiao Han, Zhi-Ming Duan, Qiang Hao, Shuai-Zhi Zheng and Ke-Zhi Wang* \\ College of Chemistry, Beijing Normal University, Beijing 100875, China
}

\section{List of contents:}

SCHEME S1: Molecular Structures of Representative Light-Switch Ru(II) Complexes for ct-DNA and Those Studied in This Paper

Page 2

Figure S1. (a) The changes in absorption spectra of Ru(bpy) $)_{2}(\mathrm{bipp})^{2+}(5.6 \mu \mathrm{M})$ upon addition of ct-DNA $(0.0-80.0 \mu \mathrm{M})$. Inset: plot of $\left(\varepsilon_{\mathrm{a}}-\varepsilon_{\mathrm{f}}\right) /\left(\varepsilon_{\mathrm{b}}-\varepsilon_{\mathrm{f}}\right)$ vs [DNA], and the nonlinear fit curve. (b) The changes in emission spectra $\left(\lambda_{\mathrm{ex}}=460 \mathrm{~nm}\right)$ of $\mathrm{Ru}(\mathrm{bpy})_{2}(\mathrm{bipp})^{2+}(5.6 \mu \mathrm{M})$ upon addition of ct-DNA $(0.0-48.0 \mu \mathrm{M})$. Inset: plot of $\left(I_{\mathrm{a}}-I_{\mathrm{f}}\right) /\left(I_{\mathrm{b}}-I_{\mathrm{f}}\right)$ vs [DNA], and the nonlinear fit curve.

Page 3

Figure S2. (a) The changes in absorption spectra of $\mathrm{Ru}(\mathrm{bpy})_{2}(\mathrm{bopp})^{2+}(5.0 \mu \mathrm{M})$ upon addition of ct-DNA $(0.0-60.0 \mu \mathrm{M})$. Inset: plot of $\left(\varepsilon_{\mathrm{a}}-\varepsilon_{\mathrm{f}}\right) /\left(\varepsilon_{\mathrm{b}}-\varepsilon_{\mathrm{f}}\right)$ vs [DNA], and the nonlinear fit curve. (b) The changes in emission spectra $\left(\lambda_{\mathrm{ex}}=460 \mathrm{~nm}\right)$ of $\mathrm{Ru}(\mathrm{bpy})_{2}(\mathrm{bopp})^{2+}(5.0 \mu \mathrm{M})$ upon addition of ct-DNA $(0.0-60.0 \mu \mathrm{M})$. Inset: plot of $\left(I_{\mathrm{a}}-I_{\mathrm{f}}\right) /\left(I_{\mathrm{b}}-I_{\mathrm{f}}\right)$ vs [DNA], and the nonlinear fit curve.

Page 4

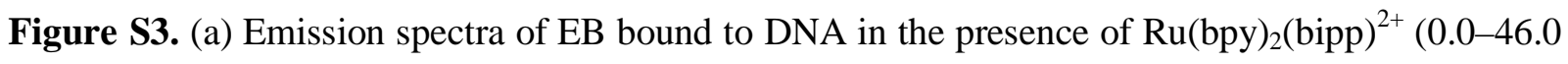
$\mu \mathrm{M})$. The arrows show the intensity changes upon increasing concentrations of the complex. Inset: emission quenching curve of DNA-bound EB by the complex. (b) Plot of percentage of free EB vs $[\mathrm{Ru}] /[\mathrm{EB}] .[\mathrm{EB}]=20.0 \mu \mathrm{M},[\mathrm{DNA}]=100.0 \mu \mathrm{M}, \lambda_{\mathrm{ex}}=537 \mathrm{~nm}$.

Page 5

Figure S4. (a) Emission spectra of EB bound to DNA in the presence of Ru(bpy $)_{2}(\text { bopp })^{2+}(0.0-20.0$ $\mu \mathrm{M})$. The arrows show the intensity changes upon increasing concentrations of the complex. Inset: emission quenching curve of DNA-bound EB by the complex. (b) Plot of percentage of free EB vs $[\mathrm{Ru}] /[\mathrm{EB}] .[\mathrm{EB}]=20.0 \mu \mathrm{M},[\mathrm{DNA}]=100.0 \mu \mathrm{M}, \lambda_{\mathrm{ex}}=537 \mathrm{~nm}$.

Page 6

Figure S5. The changes in emission spectra of $\operatorname{Ru}(b p y)_{2}(\mathrm{bipp})^{2+}-\mathrm{DNA}$ (a), and $\mathrm{Ru}(\mathrm{bpy})_{2}$ (bopp) $)^{2+}$-DNA (b) upon addition of $\mathrm{NaCl}$. Inset: salt dependence of binding constant $\left(K_{\mathrm{b}}\right)$ for the binding of the complex to ct-DNA. The slope of this plot corresponds to the $S K$. Page 7

Figure S6. Thermal denaturnation curves of ct-DNA $(50.0 \mu \mathrm{M})$ at different concentrations of $\operatorname{Ru}(\text { bpy })_{2}(\text { bipp })^{2+}(\mathrm{a})$, and $\mathrm{Ru}(\mathrm{bpy})_{2}(\text { boipp })^{2+}(\mathrm{b})$.

Page 8 
SCHEME S1: Molecular Structures of Representative Light-Switch Ru(II) Complexes for ct-DNA Reported and Those Studied in This Paper

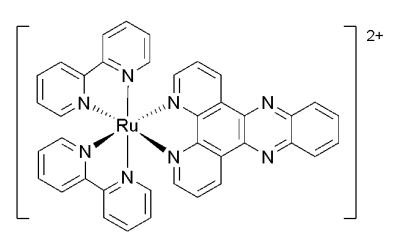

$\left[\mathrm{Ru}(\mathrm{bpy})_{2}(\mathrm{dppz})\right]^{2+}$

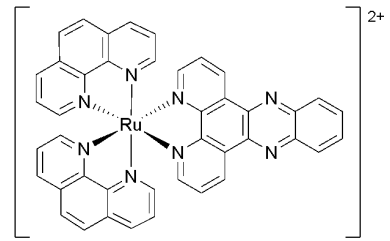

$\left[\operatorname{Ru}(\text { phen })_{2}(\mathrm{dppz})\right]^{2+}$

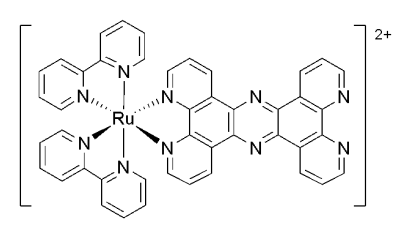

$\left[(\mathbf{b p y})_{2} \mathbf{R u}(\mathbf{t p p z})\right]^{2+}$

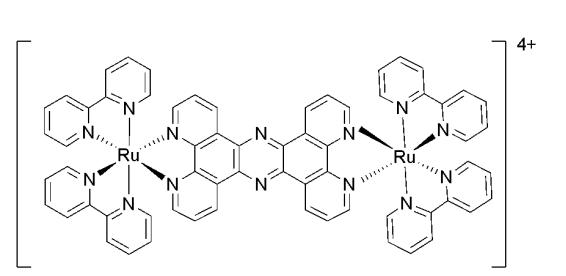

$\left[(\mathrm{bpy})_{2} \mathbf{R u}(\mathrm{tppz}) \mathbf{R u}(\mathrm{bpy})_{2}\right]^{4+}$

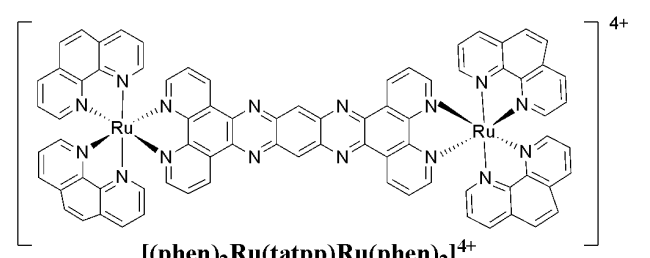

$\left[(\text { phen })_{2} \operatorname{Ru}(\text { tatpp }) \operatorname{Ru}(\text { phen })_{2}\right]^{4+}$

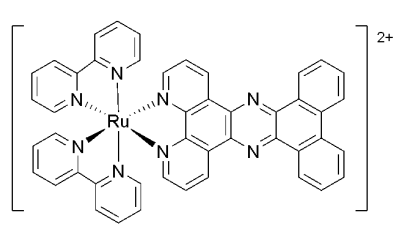

$\left[\operatorname{Ru}(\text { phen })_{2}(\operatorname{taptp})\right]^{2+}$

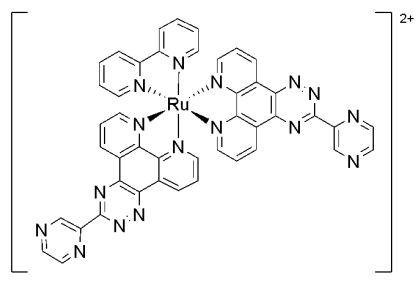

$\left[\operatorname{Ru}(\text { bpy })_{2}(\operatorname{taptp})\right]^{2+}$

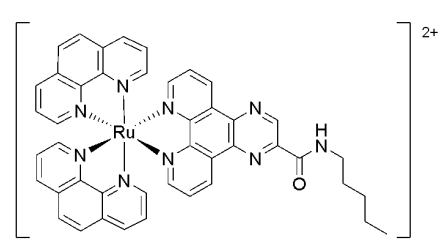

$\left[\operatorname{Ru}(\text { phen })_{2}(\text { dpqa })\right]^{2+}$

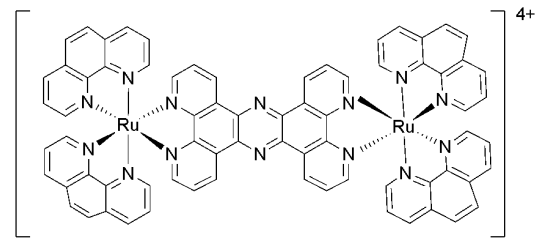

$\left[(\text { phen })_{2} \operatorname{Ru}(t p p z) R u(p h e n)_{2}\right]^{4+}$

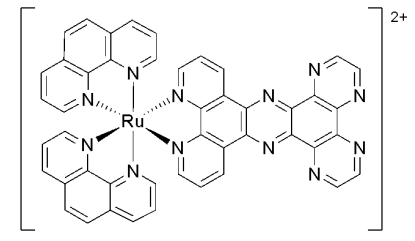

$[\text { Ru(phen })_{2}$ (phehat) $]^{2+}$

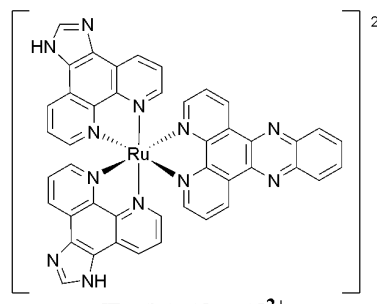

$\left[\operatorname{Ru}(\mathrm{ip})_{2}(\mathrm{dppz})\right]^{2+}$

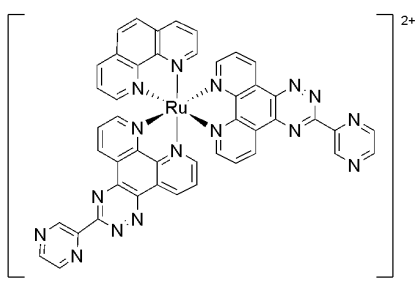

$\left[\operatorname{Ru}(\text { phen })_{2}(\operatorname{taptp})\right]^{2+}$

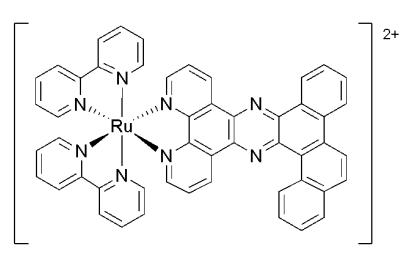

$\left[\operatorname{Ru}(\text { bpy })_{2}(\operatorname{tactp}]^{2+}\right.$

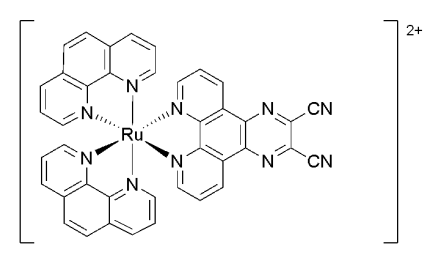

$\left[\operatorname{Ru}(\text { phen })_{2}(\text { dedpq })\right]^{2+}$

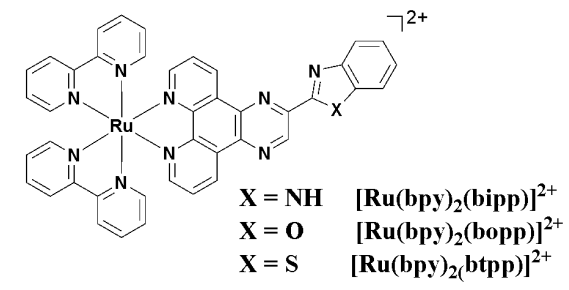



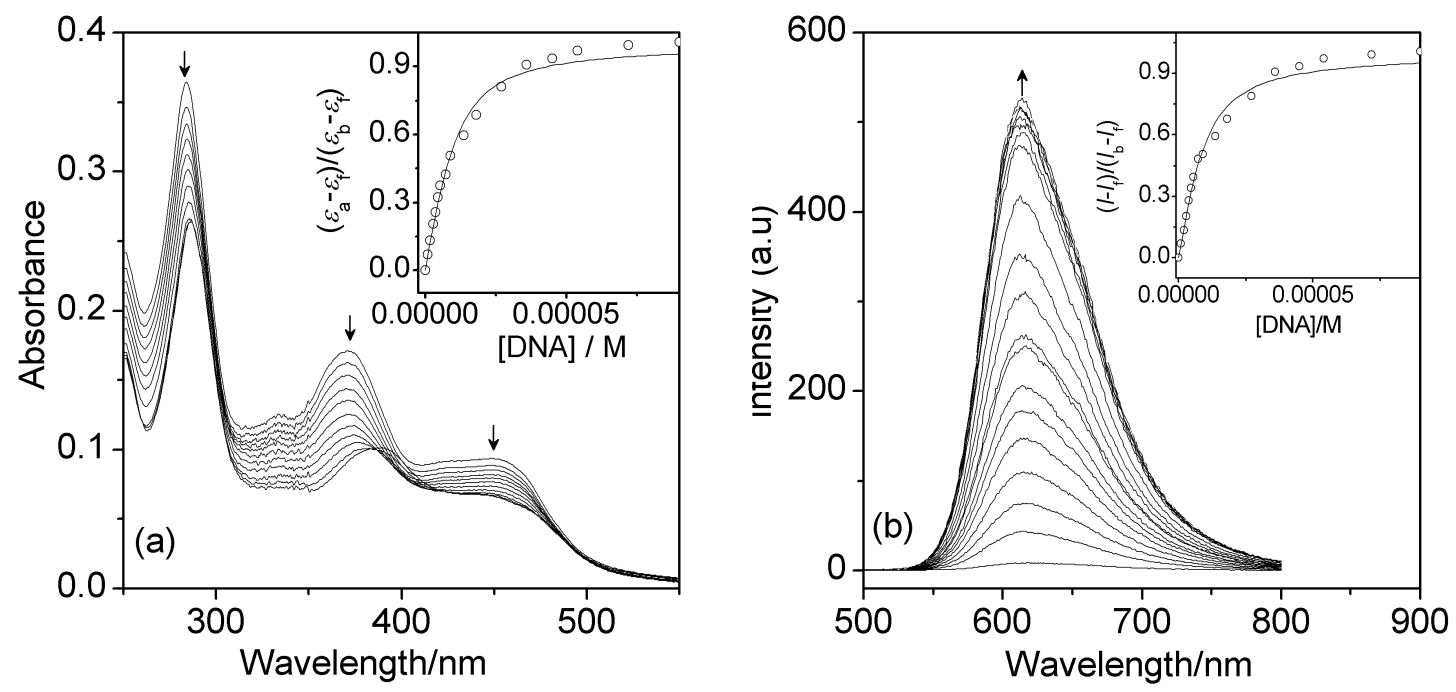

Figure S1. (a) The changes in absorption spectra of $\mathrm{Ru}(\mathrm{bpy})_{2}(\mathrm{bipp})^{2+}(5.6 \mu \mathrm{M})$ upon addition of ct-DNA $(0.0-80.0 \mu \mathrm{M})$. Inset: plot of $\left(\varepsilon_{\mathrm{a}}-\varepsilon_{\mathrm{f}}\right) /\left(\varepsilon_{\mathrm{b}}-\varepsilon_{\mathrm{f}}\right)$ vs [DNA], and the nonlinear fit curve. (b) The changes in emission spectra $\left(\lambda_{\mathrm{ex}}=460 \mathrm{~nm}\right)$ of $\mathrm{Ru}(\mathrm{bpy})_{2}(\mathrm{bipp})^{2+}(5.6 \mu \mathrm{M})$ upon addition of ct-DNA $(0.0-48.0 \mu \mathrm{M})$. Inset: plot of $\left(I_{\mathrm{a}}-I_{\mathrm{f}}\right) /\left(I_{\mathrm{b}}-I_{\mathrm{f}}\right)$ vs [DNA], and the nonlinear fit curve. 

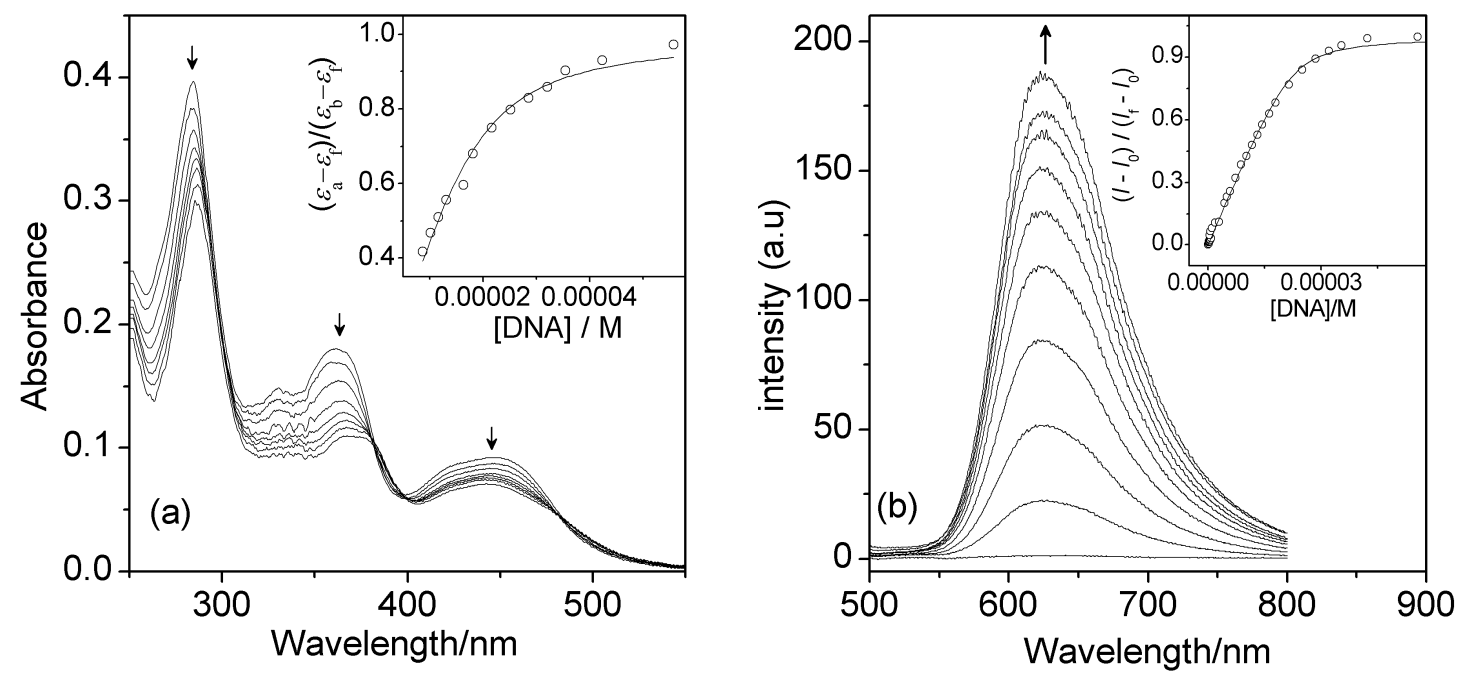

Figure S2. (a) The changes in absorption spectra of $\mathrm{Ru}(\mathrm{bpy})_{2}(\mathrm{bopp})^{2+}(5.0 \mu \mathrm{M})$ upon addition of ct-DNA $(0.0-60.0 \mu \mathrm{M})$. Inset: plot of $\left(\varepsilon_{\mathrm{a}}-\varepsilon_{\mathrm{f}}\right) /\left(\varepsilon_{\mathrm{b}}-\varepsilon_{\mathrm{f}}\right)$ vs [DNA], and the nonlinear fit curve. (b) The changes in emission spectra $\left(\lambda_{\mathrm{ex}}=460 \mathrm{~nm}\right)$ of $\mathrm{Ru}(\mathrm{bpy})_{2}(\mathrm{bopp})^{2+}(5.0 \mu \mathrm{M})$ upon addition of ct-DNA $(0.0-60.0 \mu \mathrm{M})$. Inset: plot of $\left(I_{\mathrm{a}}-I_{\mathrm{f}}\right) /\left(I_{\mathrm{b}}-I_{\mathrm{f}}\right)$ vs [DNA], and the nonlinear fit curve. 

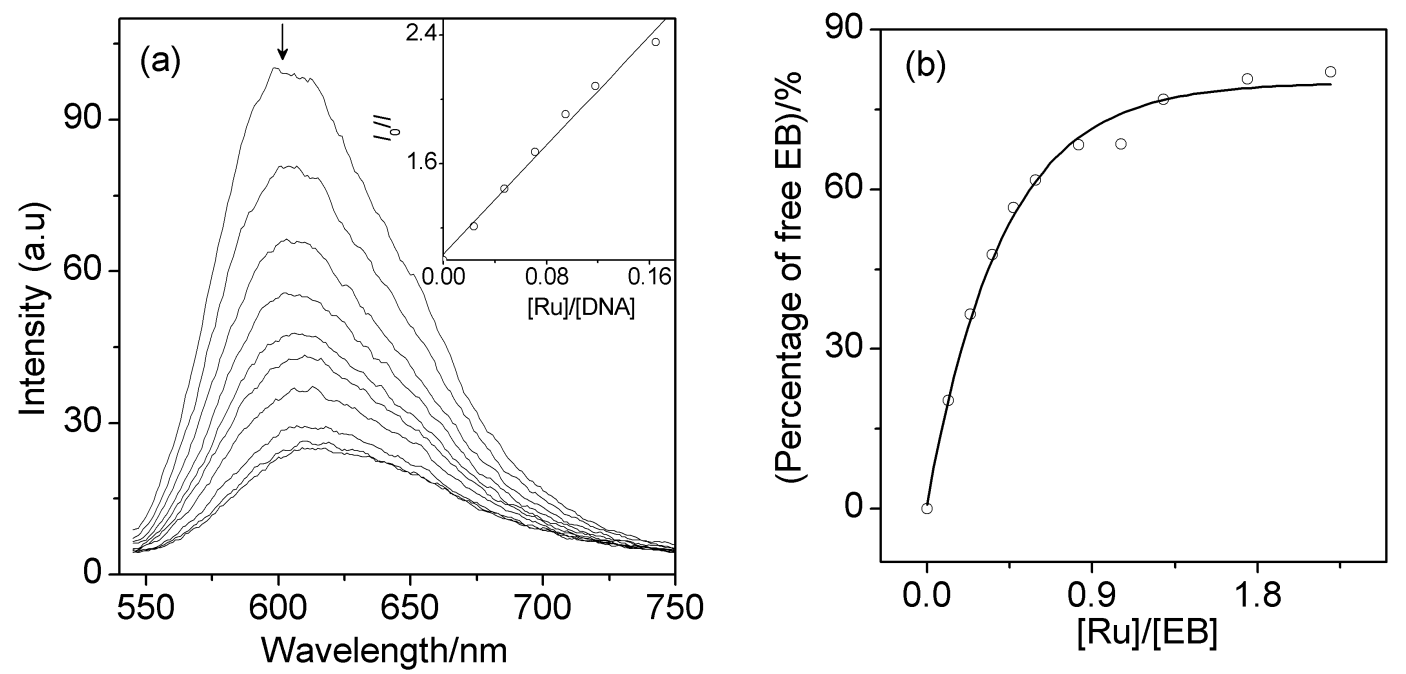

Figure S3. (a) Emission spectra of EB bound to DNA in the presence of Ru(bpy) $)_{2}(\text { bipp })^{2+}(0.0-46.0$ $\mu \mathrm{M})$. The arrows show the intensity changes upon increasing concentrations of the complex. Inset: emission quenching curve of DNA-bound EB by the complex. (b) Plot of percentage of free EB vs $[\mathrm{Ru}] /[\mathrm{EB}] .[\mathrm{EB}]=20.0 \mu \mathrm{M},[\mathrm{DNA}]=100.0 \mu \mathrm{M}, \lambda_{\mathrm{ex}}=537 \mathrm{~nm}$. 

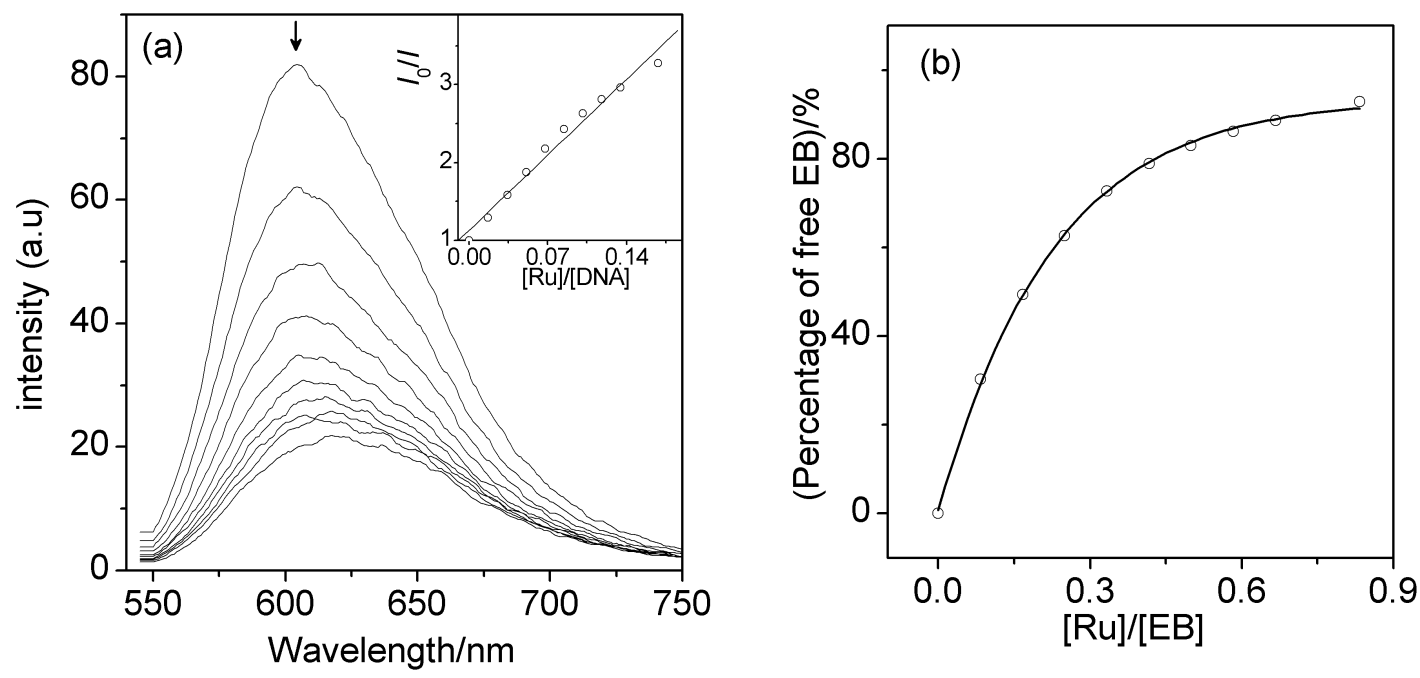

Figure S4. (a) Emission spectra of EB bound to DNA in the presence of Ru(bpy $)_{2}(\text { bopp })^{2+}(0.0-20.0$ $\mu \mathrm{M})$. The arrows show the intensity changes upon increasing concentrations of the complex. Inset: emission quenching curve of DNA-bound EB by the complex. (b) Plot of percentage of free EB vs $[\mathrm{Ru}] /[\mathrm{EB}] .[\mathrm{EB}]=20.0 \mu \mathrm{M},[\mathrm{DNA}]=100.0 \mu \mathrm{M}, \lambda_{\mathrm{ex}}=537 \mathrm{~nm}$. 

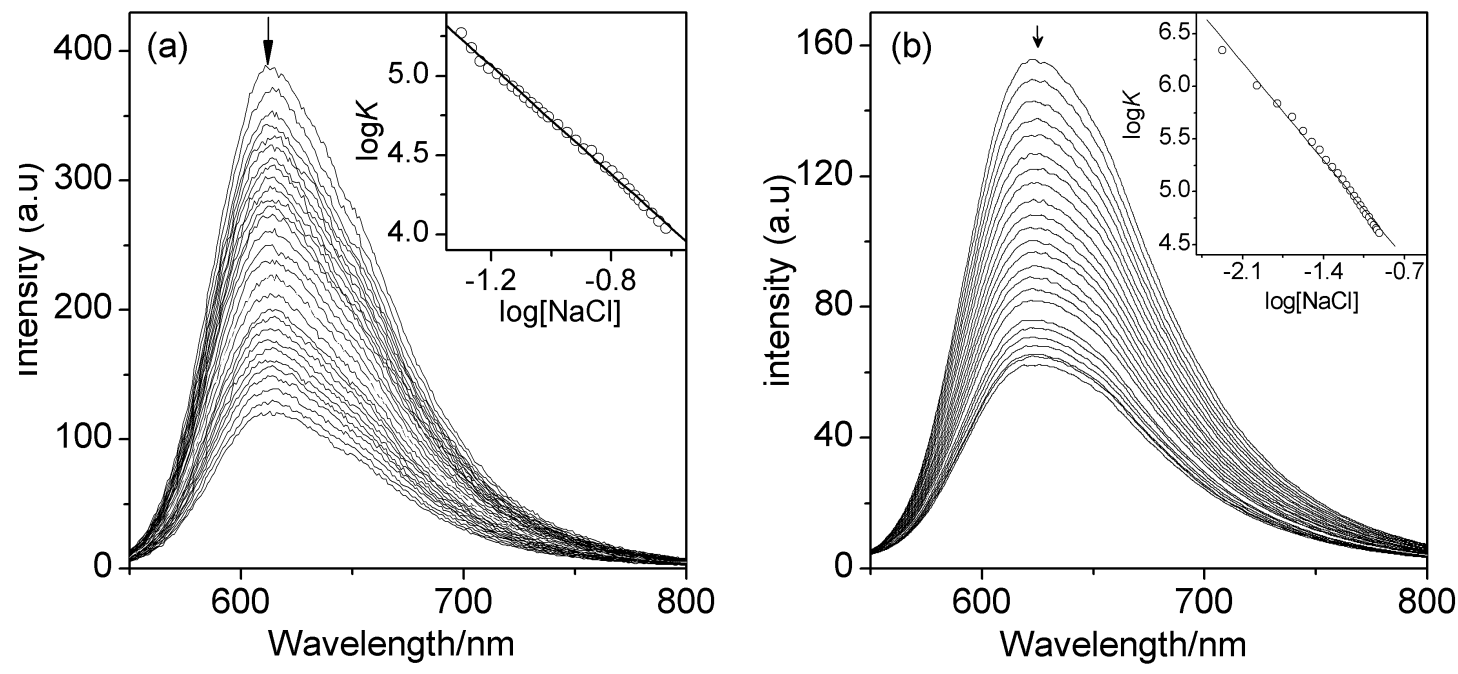

Figure S5. The changes in emission spectra of $\operatorname{Ru}(b p y)_{2}(\mathrm{bipp})^{2+}-\mathrm{DNA}$ (a), and $\mathrm{Ru}(\mathrm{bpy})_{2}$ (bopp) ${ }^{2+}$-DNA (b) upon addition of $\mathrm{NaCl}$. Inset: salt dependence of binding constant $\left(K_{\mathrm{b}}\right)$ for the binding of the complex to ct-DNA. The slope of this plot corresponds to the $S K$. 

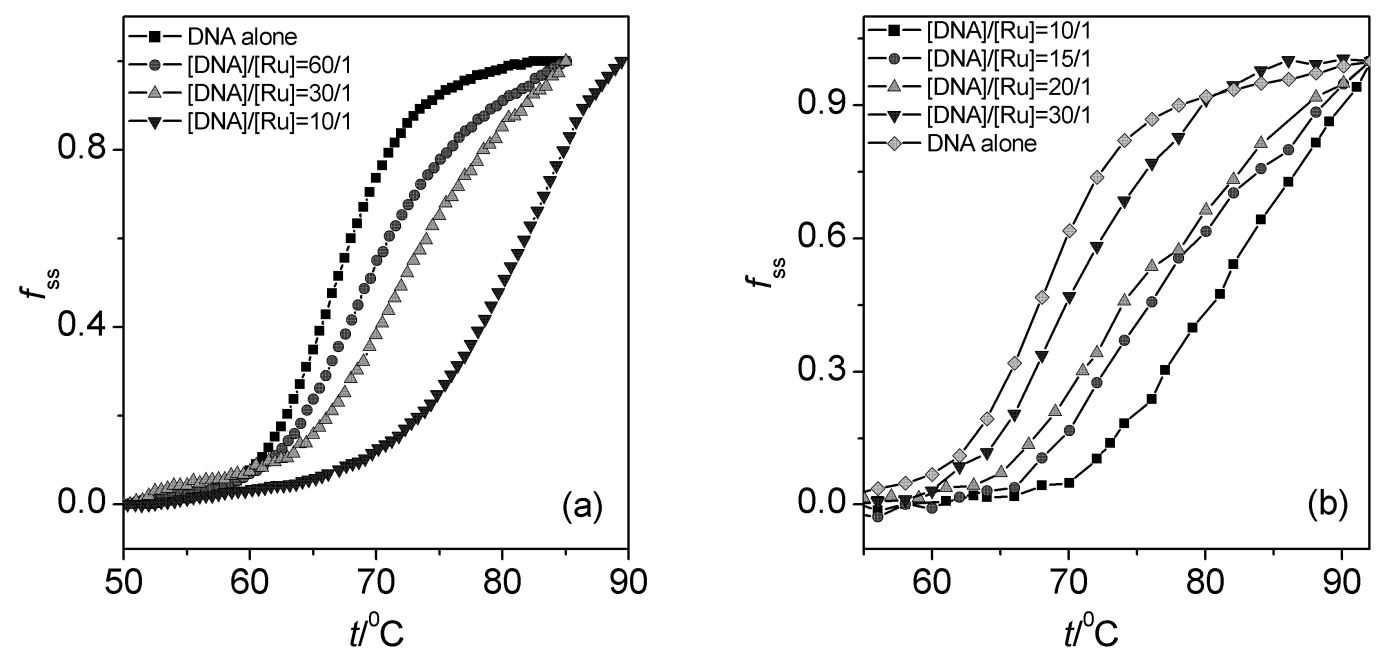

Figure S6. Thermal denaturnation curves of ct-DNA $(50.0 \mu \mathrm{M})$ at different concentrations of $\mathrm{Ru}(\mathrm{bpy})_{2}(\mathrm{bipp})^{2+}(\mathrm{a})$, and $\mathrm{Ru}(\mathrm{bpy})_{2}(\mathrm{bopp})^{2+}(\mathrm{b})$. 